\title{
Seyyah Notlarına Göre Safevilerde Düğün, Ölüm, Yas ve Bayram Merasimleri
}

\author{
Wedding, Death, Mourning And Festival Ceremonies Of The Safavids As \\ Seen By The Travellers \\ Eralp ERDOĞAN*
}

\author{
Namık Kemal Üniversitesi, Fen-Edebiyat Fakiltesi, Tarih Bölümü, eerdogan@nku.edu.tr*
}

ORCID Numarası I ORCID Number: 0000-0002-1807-2745

\begin{abstract}
ÖZ
Safevi Devleti'nde Şii inanışına uygun olarak yıl boyunca bazı dini merasimler yapılmaktaydı. 12 ayın sadece 5 ayı merasimsiz geçmekteydi. Seyyahların en çok bahsettiği dini merasimler Hz. Hüseyin anısına yapılan Muharrem ayı matemi ve Kurban merasimleriydi. Şeriat hükümlerine göre yapılan diğer merasimler ise düğün ve cenaze merasimleriydi. Safevilerde dini olmayan en önemli merasim ise yeni yıl dolayısıyla gerçekleşmekteydi. Özellikle devlet tarafından organize edilen merasimlere birçok insan katılır ve bu merasimler çok görkemli geçerdi.

Bu çalışma çeşitli tarihlerde Safevi Devleti'ne gelen 13 seyyahın gözlemlerini içermektedir. Çalışmanın asıl amacı seyyahların şahit olduğu dini ve milli merasimlerin Şii Türk Devleti olan Safevilerde nasıl gerçekleştiğinin ortaya çıkarılmasıdır. Seyahatnameler incelendikten sonra merasimlere yönelik notlar çıkarılmış ve tasnif edilerek yazılmıştır. Buna göre merasimlerin çoğu özellikle başkent İsfahan'da coşkulu bir biçimde gerçekleşmekteydi. Halkın büyük katılım gösterdiği bu törenler Safevi toplum hayatında önemli bir yer tutmaktaydı.
\end{abstract}

Anahtar Kelimeler: Muharrem Ayı, Kurban, Dügün, Nevruz, Cenaze

\begin{abstract}
Some religious ceremonies were held in accordance with the Shia belief throughout the year in the Safavids. Only 5 months out of the year were without ceremonies. Religious ceremonies most talked about by the travelers include that of the Muharram for the memory of Hz.Husain and those of the Qurban. According to Sharia laws, wedding and funeral ceremonies were also held. The most important nonreligious ceremony in the Safavids was Nawruz. Many people attended these magnificent ceremonies organized especially by the state.

This study includes observations of 13 travelers coming to the Safavid State at various times. The main purpose of the study is to reveal how religious and national ceremonies are performed in the Safavids, which is the Shia Turkish State. After examining the travelogues, notes about the ceremonies were taken and they were classified and written. Accordingly, most of the ceremonies were carried out enthusiastically, especially in the capital of Isfahan. These ceremonies had an important place in the life of Safavid society.
\end{abstract}

Key Words: Muharram, Qurban, Wedding, Nawruz, Funeral 


\section{Giriş}

Safevi Türklerinin sosyal yaşamını ortaya çıarabilmek için seyahatnamelerden olabildiğince çok faydalanmamız gerekmektedir. Çalışmamıza, Michele Membre, Pietro Della Valle, Oruç Bey, Don Garcia de Silva Figueroa, Fedot Afanisiyev Kotov, Adam Olearius, Jean Baptiste Tavernier, Jean Chardin, Sanson, Ambrosio Bembo, Engelbert Kaempfer, Gemelli Careri ve Ahmed Dürri Efendi'nin seyahatnameleri kaynaklık edecektir. Michele Membre ve Ahmed Dürri Efendi haricindeki tüm seyyahlar XVII. yüzyılda Safevileri ziyaret etmiştir. Dolayısıyla bu çalışma daha çok Safevilerin XVII. yüzyılına dair gözlemleri içermektedir. Şah Tahmasb (1524-1576) dönemine tanıklık eden Michele Membre'ye bir kurçi dügününe şahit olması hasebiyle yer verilmiştir. Şah Hüseyin (16941722) dönemine tanıklık eden Ahmed Dürri Efendi'nin seyahatnemesinde ise Nevruz hakkında kısa bir malumat bulunmaktadır.

Adı geçen tüm seyyahlara göre Şiiliği benimsemiş olan Safevi Devleti’nde yıl boyunca çeşitli bayramlar kutlanır ve anma merasimleri yapılırdı. Safeviler için önemli olan dini günler ise Kaempfer ${ }^{1}$ tarafından bir özet niteliğinde kaleme alınmıştır. Buna göre Muharrem ayında Hz. Hüseyin'i anma törenleri yapılırdı. Safer ayının 20. gününde Hz. Hüseyin'in kesilen başı ile vücudunun birleştiğine inanılıyordu ve bunu "ser u ten" olarak adlandırıyorlardı. Safer ayının 28. günü Hz. Hasan'ın zehirlenmesinin yasını tutuyorlar ayrıca bu ayın son gününde gökten binlerce belanın yağdığına inanıyorlardı. Bu belaları defetmek için ise çatıdan aşağıya saksılar atıyorlardı. Rebiülevvel ayının 9. günü Hz. Ömer'i öldüren değirmenci anısına bir festival düzenlenirdi ve bu ayın 17. günü Hz. Muhammed'in doğum günü kutlanırdı. Rebiülahir, Cemaziyelevvel, Cemaziyelahir ve Receb aylarında herhangi bir anma veya kutlama merasimi bulunmuyordu. Şaban ayında bir meleğin, kendi adlarının yazılı olduğu defteri cennete götürdüğüne inanırlar ve bu günü "ruz-1 berat" olarak adlandırırlardı. Ramazan ayında oruç tutarlardı. Yine bu ayın 19., 20. ve 23. günü yapılan duaların kabul olduğuna inandıkları için o günlerde camileri doldururlardı. Şevval ayının ilk günü zekat vermeye adanmıştı. Zilkade ayında herhangi bir anma töreni yoktu. Zilhicce ayının 10. günü kurban merasimi gerçekleştirilirdi. Ayrıca bu ayın 18'ini Gadir-i hum dedikleri, Hz. Muhammed'in Hz. Ali'yi hilafete atadığı gün olarak kutlamaktaydılar (Keampfer, 2018, s. 131-133).

Seyyahlar özellikle Muharrem ayı ve Kurban merasimi hakkında önemli bilgiler vermişlerdir. Bunun yanı sıra milli bir bayram niteliği taşıyan Nevruz ile düğün ve cenaze merasimleri hakkında vermiş oldukları bilgiler de makalemizde işlenecektir.

\section{Düğün Merasimi}

Safevilerde genellikle erken yaşta evlilik görülmekteydi. Özellikle, varlıklı insanlar arasında şeriatın kendilerine verdiği izinle birlikte çok eşlilik yaygındı. Tavernier'e göre erkek çocuklar 9-10 yaşlarında nişanlanıyordu ve evlilikler görücü usulü ile gerçekleşiyordu (Tavernier, 1382, s. 315). Evlilik çağına gelen gence uygun bir kız bulunduğu zaman, öncelikle bir kişiyi kızın yanına gönderirler ve böylece kızın evlilik hakkındaki görüşünü öğrenirlerdi. Bu işi gencin anne ve babasının yapması uygun görülmezdi. Zira onların kızı görmesi ve onunla sohbet etmesi hoş karşılanmıyordu. Kızın rızası olduğu bilgisi gelince, damat adayı yakın arkadaşlarından iki kişiyi, evlilik konusunu konuşmak üzere kızın babasının yanına göndermekteydi (Olearius, 1369, s. 665). Kız babasının arkadaşları da bu görüşmeye katılır ve ona destek olurlardı. Görüşme olumlu geçer ve babasının rızası alınır ise evlilik ve mehir ${ }^{2}$ şartları konuşulmaya başlanırdı. Damat, kararlaştırılan mehiri düğünden

\footnotetext{
${ }^{1}$ Kaempfer hakkında detaylı bilgi edinmek ve Kaempfer 'in Şah Süleyman hakkındaki gözlemleri için Bkz. (Keser, 2019).

2 İslamiyet öncesi Türklerin "kalın" uygulaması, İslamiyet sonrasında yerini mehir'e bırakmıştır. İslam hukukuna göre nikah esnasında kadına ödenecek mehrin miktarı ve ödeme şekli kararlaştırılmalıydı. Mehir
} 
birkaç gün önce gelinin evine giderek verirdi. Ya da mehiri ödeyeceğine dair bir kağıt imzalar ve bu miktar sonradan alınırdı. Mihrin bir miktarını gelinin anne ve babası süt ve yetiştirme hakkı olarak alır, kalanını da geline verirlerdi (Olearius, 1369, s. 666).

Tüm şartlar yerine getirildikten sonra nikah akdi gerçekleştirilirdi. Eğer nikah, şehirde gerçekleşirse Kadı'ya, köyde gerçekleşirse Molla'ya müracaat edilirdi. Damat ve gelin kendi başlarına Kadı veya Molla'nın huzuruna çıkamadığı için kendilerine bir vekil tayin ederdi. Nikah kıyılacağı zaman gelin, damat, vekiller ve Molla kimsenin bilmediği veya gözlerden uzak bir yere giderek nikah akdini gerçekleştirirlerdi. Etraftan birilerinin büyü yapabileceğine dair korkuları bu durumun sebebiydi. Nikah esnasında ise yine büyü yapılmaması için odada bulunan herkes ellerini öne doğru çıkarmaktaydı. Nikah kıyıldıktan sonra akidname imzalanır ve nikah bitirilirdi (Olearius, s. 1369, 666).

Dügün öncesi damat, geline kıyafet ve masraflar için bir miktar para gönderirken, karşıllı̆ında kız tarafı da bazı eşyalar gönderirdi. Tüm bu gidiş gelişler tanıdık kadınlar vasıtasıyla yapılırdı. Dügün günü ise gelinin çeyizi, hamalların sırtında, saz ve davul eşliğinde damadın evine gönderilirdi (Tavernier, 1382, s. 315). Düğün günü gelinin tüm akrabaları ve yakınları damadın evinde toplanırdı. Herkes en güzel elbiselerini giyerdi. Özellikle damadın sağdıcı damadın giydiği elbisenin renginden giymeye özen gösterirdi. Üzerinde ay ve güneş resmedilmiş olan bir kumaşı yüzüne örten gelin ise at üzerine bindirilir ve damadın evine doğru yola çıkardı (Bembo, 2007, s. 353-354; Oruç Bey Bayat, 2014, s. 42; Pietro Della Valle, s. 1348, 446). Ellerinde davul ve saz olan birkaç çalgıcı önden giderek müzik çalardı. Geline eşlik eden kadınların ellerinde mumlar bulunurdu (Tavernier, 1382, s. 316). Gelini almak için yola çıkan damat, mumlar ve meşaleler eşliğinde yola devam ederdi. İki taraf buluştuğunda bir tür müzik aleti olan şipur ve kurna sesleri yükselirdi. Hep beraber gelin evine ulaştıktan sonra molla bir kez daha evlilik koşullarını tekrar ederdi (Careri, 1969, s. 132-133). Burada bir gün boyunca eğlence düzenlenir ve misafirlere yemek verilirdi (Oruç Bey Bayat, 2014, s. 42; Bembo, 2007, s. 354). Misafirlere yapılan bu masraflar, eğer damat zenginse onun tarafindan karşılanır, damat, düğün öncesi gelin evine yiyecek gönderirdi (Olearius, 1369, s. 667).

Damat gelini almaya giderken gelinin de onları karşılamak üzere at üzerinde yola çıkması konusunda belirsizlik vardır. Oruç Bey ve Ambrosio Bembo gelinin at üzerinde, kendisine eşlik eden birçok kişiyle birlikte damadı karşılamaya çıktığını ve buluştuktan sonra gelin evine geri döndügünü yazarken, diğer seyyahlarda buna rastlamıyoruz. Gemelli Careri damadın kız tarafından gönderilen birileri ile karşılandığını ve gelin evine getirildiğini yazmaktadır (Careri, 1969, s.132). Tavernier, gelinin çalgıcılar ve ellerinde mum taşıyan kadınların eşliğinde evden çıktığı zaman damadın evine gittiğini (Tavernier, 1382, s. 316), aynı şekilde Adam Olearius da gelinin, damat geldikten sonra, at, katır veya deveye bindirilerek, eteklerine kadar uzanan kırmızı uzun bir tülbentle damadın evine doğru yola çıktı̆̆ını yazmaktadır (Olearius, 1369, s. 667).

Gelin evinde erkekler için ayrılan oldukça güzel süslenmiş bir oda bulunurdu. Burada çalgılar eşliğinde oynanır ve oyun oynayan kişiye paralar saçılırdı. Saçılan bu paraları toplama hakkı ise çalgıcılara aitti. Kadınlar da aynı şekilde ayrı bir odada eğlenirdi. Oynarken alınlarına yapıştırılan paralar yere düşerse çalgıcılar toplardı. Oyun sona erdiğinde, kız evinde akşam yemeğine oturulurdu. Ertesi gün tüm refakatçiler görkemli bir ziyafetin olduğu damat evine gider ve öğle yemeğini orda yerdi (Oruç Bey Bayat, 2014, s. 42; Bembo, 2007, s. 354).

Damadın evinde erkekler ve kadınlar yeniden ayrı odalara alınırdı. Daha sonra damat gerdeğe girmek üzere gider ve eğlenceye devam edilirdi. Eğer kız bakire ise düğün 3 gün 3 gece boyunca devam ederdi. Ancak bakire değilse gelin evden kovulur ve düğün biterdi. Adam Olearius, eğer gelin bakire değilse damadın onun kulak ve burnunu kestiğini yazmaktadır (Olearius, 1369, s. 667). Gelinin

olarak para, eşya ve ekonomik değeri olan bir mülk mehir olarak belirlenmelidir. Mehir tamamen kadının malıdır ve istediği gibi tasarruf edebilir. Detaylı bilgi için Bkz. (Aydın, 2003) 
bakire olduğu ise 2 yaşlı kadın tarafından getirilen kanlı çarşafla duyurulurdu (Oruç Bey Bayat, 2014, s. 43; Bembo, 2007, s. 354). Gerdekten sonra gelin genellikle odada kalır ancak damat odadan çıkarak arkadaşlarının yanına giderdi. Eğer ortamda dini bir görevli veya ulemadan biri varsa içki içilmez ve dans edilmezdi. Sadece dini kitaplar okunur ve dini sohbetlerde bulunulurdu (Olearius, 1369, s. 667). Sonraki günün gecesinde kına yakılırdı. Gelen misafirlere içerisinde 2-3 kaşık kına bulunan mendiller verilirdi. Kinadan sonra misafirler gelin ve damada hediyelerini takdim ederdi (Olearius, 1369, s. 668). Ambrosio Bembo bütün kadınların ve bazı erkeklerin tırnaklarını ve ellerini kına ile boyadığını yazmaktadır. Bazıları ise burunlarını deler ve oraya bir yüzük takardı (Bembo, 2007, s. 354).

Dügün merasiminin bitmesinden sonra kararlarına göre gelin ve damat, damadın anne ve babasının evinde yaşardı. Gelin, kayınpederinin yanında çarşafsız dolaşmaz ve sohbet etmezdi. Gerektiğinde meramını işaretle anlatırdı. Bu durum 1 sene boyunca devam eder ve kayınpederin geline 1 sikke altın vermesiyle son bulurdu. Altını alan gelin kayınpederiyle konuşmaya başlardı. Ancak örtünme konusunda herhangi bir esneklik olmuyordu. Gelin, yemeği bile yüzüne örttüğü paşmak ile yerdi (Olearius, 1369, s. 669).

Yüksek mevkideki insanların düğünleri ise daha uzun sürerdi. Chardin, Nazır'ın oğlu ile Divanbeyi’nin kızının düğününde bulunmuştu ve bu düğün 14 gün sürmüştü. İlk üç gün, dügünde sadece gelin ve damadın yakınları ile arkadaşları bulunmuştu. 4. gün saraylılar, 5. gün Şah'ın yakınları, 6. gün ordu mensupları, 7. gün ileri gelen ruhani emirler, 8. gün vezir-i azam, 9. gün Şah ve 10. gün mühürdar ile münşiler düğüne davet edilmişti. Kalan 4 günde ise saraydaki diğer görevliler ve seçkinler ağırlanmıştı. Nazır, düğününe teşrif eden bu kişilere çeşitli hediyeler vermekteydi. Chardin'e de bir buket gül ile birlikte tatlı ve meyve göndermişti (Chardin, 1993, CII, s. 628).

Membre ise ilginç bir seremoniden bahsetmektedir. Şah Tahmasb döneminde Safevi sarayında bulunan Membre bir kurçinin ${ }^{3}$ dügün törenine denk gelmiştir. Bir odada yan yana oturan kişiler bir saat boyunca halifenin önderliğinde "La ilahe illallah" diyerek kelime-i tevhid getirmişti. Ardından Hatayi Divanı'ndan şiirler okunarak Şah İsmail ve Şah Tahmasb'a övgüler dizilmişti. Bunun bitiminden sonra biri tamburla oturmuş ve sesli bir şekilde odada bulunanların isimlerini birer birer söylemeye başlamıştı. Adları söylenen herkes "şah baş" diyerek adlarını okuyan kişiye para vermekteydi. İsim okuma bittikten sonra hepsi birer birer odanın ortasına gelerek yere doğru uzanıyordu. Elinde sopa bulunan halife onlara sırayla değnekle vuruyor, ardından vurduğu kişinin kafasını ve ayağını öpüyordu. Bu seremoninin nedeni ise hiçbir kurçinin Şah'ın izni olmadan evlenemiyor olmasıydı. Vurma işlemi bittikten sonra tambur ve diğer müzik aletlerini çalarak Osmanlıları aşağılayan şarkılar söylemişlerdi. Örneğin, Tebriz'e gelip toplarını nasıl kaybettiklerine ve Şah'ın Osmanlı topraklarına girerek nasıl savaştığına dair birçok hikaye, şarkı şeklinde söylenmişti. Erkekler bir odada kadınlar başka bir odada eğlenerek düğün merasimi gerçekleşmişti (Membre, 1993, s. 42-43).

\section{Cenaze Merasimi}

Safevi kültüründe biri hastalandığı zaman hasta olan kişinin evinin çatısına herkesin görebileceği bir ateş yakı1ırdı. Bu şekilde çevredeki insanların hastalıktan haberdar olması sağlanır ve onlardan dua etmesi beklenirdi. Hasta vefat ettiği zaman kadınlar ağıtlar yakarak saçlarını yolardı. Hastanın ölüm haberi öncelikle o yerin yöneticisine veya kadısına bildirilirdi. Kadı ölüm kağıdını imzalar ve cenazenin kaldırılmasına onay verirdi. Cenaze defnedilmeden önce bir gassal ölüyü yıkar ve ardından cenaze omuzlar üzerinde mezara götürülürdü. Mezara götürülürken elinde alem taşıan birçok kişi cenazeye eşlik ederdi. Alemdarlar "Allah Allah" diyerek yürürdü. Ayrıca cenazede ağlaması için bazı kişilere para verilirdi (Tavernier, 1382, s. 317; Careri, 1969, s. 151). Ölünün

\footnotetext{
${ }^{3}$ Safevi ordusunda önemli bir birlik olan kurçiler, saltanatın hassa kuvvetleriydiler. Detaylı bilgi için Bkz. (Erdoğan, 2015).
} 
naaşının 3 saatten fazla bekletilmemesine özen gösterilirdi. Eğer kişi gece ölmüşse sabaha kadar bekletilir ve mümkün olduğu kadar kısa sürede defnedilirdi. Defnedilirken yüzü batıya doğru döndürülürdü. Defnedildikten sonra Molla, Kur'an ayetleri okur ve bir avuç toprağı ölünün üzerine serperdi. Ardından mezardan 7 adım uzaklaşırdı. Bunun sebebi o geriye gittikten sonra sorgu melekleri Münker ile Nekir'in geldiğine inanmalarıydı. Biraz durduktan sonra geri gelir, tekrar Kur'an ayetleri okur ve merasimin bitmesiyle orayı terk ederdi. Eğer müteveffa zengin ise birkaç gün hayırda bulunulur, özellikle 3. gün fukara ve akrabalara yemek verilirdi. Çok zengin olan insanlar ise 7. ve 40. günün gecesinde de yemek verir ve fukaraya sadaka dağıtırdı (Olearius, 1369, s. 768).

Ölen kişi ileri gelen emirlerden ise daha kapsamlı bir cenaze töreni yapılırdı. Ölen kişinin atları ve özel eşyaları da kendisiyle birlikte kabristana götürülürdü (Tavernier, 1382, s. 320). Sağlığında kendisine hizmet edenler yarı çıplak şekilde göğüslerine vurarak cenazenin önünde yürürler ve vücutlarını tırmalayarak kanatırlardı. Aynısını müteveffanın oğullarının da yapması gerekirdi (Oruç Bey Bayat, 2014, s. 40). Adam Olearius, aşırı şarap içmekten dolayı ölen emirlerden birinin cenaze törenini müşahede etmişti. Verdiği bilgilere göre her birinin elinde büyük bayraklar olan altı kişi önden hareket etmekteydi. Art arda hareket eden dört at görülüyordu. İlk atın üzerine müteveffanın ok ve yayı, sonraki atların üzerine ise elbiseleri ve diğer malzemeleri konulmuştu. Bu atların ardından bir katır hareket ediyordu. Üzerinde müteveffanın bir nökeri oturmakta ve onun mendili ile sarığını elinde tutmaktaydı. Ayrıca sekiz kişi kafalarının üzerinde, içinde tatılar olan büyük siniler taşıyordu. Her sininin ortasında mavi renkli kağıda sarılmış olan büyük bir şeker vardı ve onun etrafinda üç adet mum yanıyordu. Birkaç kişi ellerinde davul ve zillerle hareket ediyordu (Olearius, 1369, s. 769). Beyaz sarıklı sufiler bu grubun arkasında muhtemelen ilahi söylüyorlardı. Sufilerin ardından "Allahu ekber, Lâ ilahe illallah” diyerek göğüsleri çıplak, feryat eden bazı adamlar geliyordu. Sağ eli ve omzu çıplak olan üç gulam kendilerine zarar veriyor ve ellerinden kan akıyordu. Üzerinde elma ve müteveffanın kadınlarının saçlarından tutamların bulunduğu üç tane ağaç dalı da bir vefa nişanesi olarak bu törende taşınmaktaydı. Tabutun üzerinde ibrişim bir şal vardı. Cenazenin arkasında birkaç kişi tarafından üzerinde bir çocuğun oturduğu bir koltuk taşınıyordu. Çocuk burada Kur'an okuyordu. Onların peşinden ise müteveffanın eşleri, akrabaları ve yakınları geliyordu (Olearius, 1369, s. 770).

Oruç Bey, taşıdıkları bu yemyeşil yapraklarla donatılmış olan ağacın dallarına renkli kağıtlar, türlü türlü kurdeleler ve mevsimine uygun meyvelerin asıldığını not etmektedir. Bu şekilde yıkamaya götürülen cenaze kefenlenir ve kabristana doğru götürülürdü. Yolda gördükleri her yoksula yanlarında getirmiş oldukları yiyeceklerden vermekteydiler. Müteveffanın akrabaları bir yıl boyunca, her gün mezarın başına giderek Kur'an okuyup dualar ederdi (Oruç Bey Bayat, 2014, s. 40). İleri gelenler ve zenginler genellikle Mekke veya Meşhed'e gömülmeyi vasiyet ederdi. (Tavernier, 1382, s. 321). Şah Tahmasb döneminde ise Şah'ın lütfunu kazanmış kişiler Erdebil'e gömülürdü (Membre, 1993, s. 40).

\section{Muharrem Ayı ve Aşure Merasimi}

İslam dünyasında Aşure günü olarak kutlanan Muharrem ayının 10. günü, Hz.Hüseyin'in Kerbela'da öldürülmesinden sonra Şiiler için bir matem günü halini almıştır. Emevilerin iktidara gelmesiyle birlikte Kerbela olayını unutturmak için Şiilerin Aşureyi yas günü ilan etmesine karşlık, bu günü bayram havası içerisinde kutlama yoluna gidilmiştir. Büveyhiler ve Fatımiler zamanında da bu gün matem günü olarak benimsenmiştir. Eyyubiler zamanında ise matem günü olarak değil, vaktiyle Emevilerin yaptığı gibi bir sevinç günü olarak kutlanmaya başlanmıştı. Ancak Aşure günü matem törenleri, Safevi Devleti'nin kurulması ile birlikte Şii varlığının bir parçası olmuştur (Baş, 2014, s. 175,178).

Muharrem ayının ilk 10 günü boyunca düzenlenen bu matem törenleri Safevi Devleti'nde 
önemli bir yere sahipti. Halk her gün sokaklarda toplanır ve Ravzatü'ş-Şühedâ'dan ${ }^{4}$ bölümler okurdu. Özellikle kadınlar sinelerine vurarak "ah Hüseyin şah Hüseyin” diye.ağlardı. Akşama doğru, insanlar bir kez daha hanlarda, meydanlarda ve çeşitli yerlerde büyük bir coşkuyla toplanırdı. Toplandıkları yerlerde odunlar yığarak ateş yakarlar ve ateşin üzerinden atlarlardı. Bazen de Hz. Hüseyin için ağlarlar veya ateşin etrafında dönerek zikir yaparlardı. Zikir esnasında gögüslerine vururlardı. Bu gösteri insanlar yorulana kadar birkaç saat boyunca sürerdi (Keampfer, 2018, s. 129; Pietro Della Valle, s. 1348, 125).

Matem günleri boyunca camide yer bulmak zor olduğu için zengin ve soylu kadınlar hizmetkarlarını, vaaz başlamadan önce yer tutmaları için camiye gönderirdi. Buna rağmen yer kavgaları eksik olmazdı. İsfahan'ın en iyi mollaları tarafından verilen bu vaazlarda coşkulu bir şekilde Hz. Hüseyin'in katledilişi konu.edilirdi. Aynı zamanda Hz. Ebu Bekir, Hz. Osman ve Hz. Ömer lanetlenirdi. Mollalar vaazdan sonra caminin kapısında dururken binadan çıkan erkekler ve kadınlar onlara para, giysi ya da sarık bağışlardı (Santamaria, 2015, s. 52; Don Garcia, 1984, s. 310).

Yas günlerinde siyah renkli elbiseler giyerlerdi. Hiç kimse saçını, sakalını tıraş etmez ve hamama gitmezdi. Kendilerini her türlü zevkten mahrum bırakırlardı. Bu günlerde sokaklarda birçok dilenci görülmekteydi. Bu dilenciler Sadaka toplamak için çeşitli yöntemler kullanmaktaydılar. Onlardan bir grup kendilerini boyunlarına kadar, çıplak şekilde toprağa gömdürüyor ve sabahtan akşama kadar orda kalıyordu (Pietro Della Valle, 1348, s.123). Bunların arkadaşları da yoldan geçenlerden ve orda bulunanlardan sadaka topluyordu. Toprağa gömülen kişi gerçekten toprakla temas etmiyordu ancak halk öyle düşünüyordu. Daha önceden toprağa gömülü olan bir sepetin veya küpün içine giren adam, akşam olunca arkadaşlarının yardımıyla oradan çıkıyordu. Yemek yiyor, ihtiyaçlarını gideriyor ve güneş doğmadan tekrar toprağa gömülüyordu. Daima orda olduğunu düşünen insanlar ise ona saygı duyuyor ve yasın sonunda onu oradan coşkuyla çıkarıyordu (Don Garcia, 1984, s. 312-313). Sadece avret yerleri siyah bir keseyle örtülmüş olan çıplak diğer bir topluluk ise meydanlarda ve sokaklarda gezerek sadaka topluyordu. Bu kişilerin yanındaki diğer insanlar ise çıplak şekilde yürüyor sopalarla birbirlerinin bedenine vuruyorlardı. Hazin sesler çıkaran bu grubun etrafinda toplanan kişiler onlara para veriyordu (Pietro Della Valle, 1348, s. 123-124). Yine 10 gün boyunca yalınayak ve üst tarafı çıplak, yüzlerini ve vücutlarını siyaha boyamış olan iki adam da sokak sokak dolaşarak muhtemelen sadaka topluyordu. Bu kişiler taşlara vurarak "Hüseyin Hüseyin Ya Hüseyin" diyorlard1 (Kotov, 1959, s. 31-32).

Bazı kadınlar bu günlerde ihtiyaç sahipleri için sadaka topluyordu. Bu kişiler seçkin ve pahalı elbiselere sahipti ve yüzlerini peçe ile örtüyordu. Aynı şekilde bazı fahişeler ${ }^{5}$ de ince bir elbise giyerek fakir insanlar için para toplamaktaydı. Bunlar, Muharrem ayında yalnız veya yanında hizmetkarlarla şehre geliyordu. Bu kişiler Çok güzel giyimli ve iyi huyluydular. Ellerinde ağaçtan bir sandık veya küçük altın renkli bir kutu taşımaktaydılar. Para isterken gözlerini insanlardan kaçırıyor, haya ile yere bakıyor ve konuşmuyorlardı. Topladıkları bu sadakaları daha önceden bildikleri ihtiyaç sahiplerine veriyorlardı. Tüm kadınlar matem süresince evde dahi peçelerini çıkarmıyor ve tüm işlerini bu şekilde yapiyordu (Don Garcia, 1984, s. 313).

\footnotetext{
${ }^{4}$ Hüseyin Vaiz Kaşifi tarafından yazılan bu eser, Sultan Hüseyin Baykara'nın torunu Seyid Mirza Abdullah'ın isteği ile 1502 yılında yazılmışıır. Eser, Kerbela olaylarını kimi yerde manzum kimi yerde nesir olarak anlatmaktadır.

${ }^{5}$ Fahişelerin bu tarz yardım faaliyetlerine katılması başka bir yerde konu edilmemektedir. Çeviri hatası olabileceğine dair şüphe uyandırdığı için eserin İngilizce çevirisine de müracaat edilmiştir. İngilizce çevirisinde "courtesan" tabiri kullanılırken Farsça çevirisinde "rusbiha" kullanılmaktadır. Dolayısı ile fahişe tabiri doğru bir kullanım olacaktır.
} 
Muharrem ayının 10. yani son günü ise çevre mahallelerden gelen iki grup alem taşıyarak yola düşüyordu. ${ }^{6}$ Atlarının üzerinde çeşitli silahlar ve birkaç sarık vardı. Yanlarında getirdikleri her devenin üzerinde ise Hz. Hüseyin'in çocuklarını temsil eden 3-4 çocuk bulunuyordu. Bunun yanı sıra grup içinde birkaç tane tabut taşınıyordu. Tabutların üzerinde yeşil renkli bir sarık vardı ve bir kılıç yerleştirilmişti. Her grup bir çatışmaya hazır şekilde ilerliyordu. Zira bu günde yapılacak olan bir kavgada, ölen birinin doğrudan cennete gideceğine inanıllyordu (Pietro Della Valle, 1348, s. 125). Bu grupların birbiriyle çatışmaması için bazı önlemler alınmakla birlikte bu önlemler pek bir işe yaramamaktaydı. Pietro Della Valle'nin bizzat şahit olduğu bir olaya göre iki grup Şah'ın kasrının önünde çatışmaya girmişti. Şah'ın kasrına yakın olan grup saldırıya geçeceği zaman alemlerini ve bazı eşyalarını kasrın içine götürüp bırakmıştı. Zira bu eşyalar diğer grup tarafından ele geçirilirse yağma ediliyordu (Pietro Della Valle, 1348, s. 126).

$\mathrm{Bu}$ törende çocuklar develere çıplak şekilde oturtulur ve tabutların önünde giderlerdi. Giderken "Hüseyin" diye bağırırlardı. Gözlemlere göre Tabutların önünde alem, zırh, yay, sadak, kılıç ve mızrak taşıyanlar vardı. Ayrıca vücutları, yüzleri ve kafaları kanla kaplı iki küçük çocuk at üzerinde geliyordu. Bir diğer atın üzerinde ise koyun derisine sarılmış olan çıplak bir adam binmişti. Bunun yanı sıra içi samanla doldurulmuş, oku, yayı ve sadağı olan temsili bir kukla taşımaktaydılar. Bu kukla oturur vaziyetteydi ve başında beş parmaklı bir miğfer vardı. Düşmemesi için onu yandan destekleyerek ona tükürüyorlar ve onu lanetliyorlardı. Kadınlar ağlıyor, erkekler ve erkek çocuklar başlarını ve koltuk altlarını ustura ile kazıyorlardı (Kotov, 1959, s. 32; Keampfer, 2018, s. 130). Kollarına ve göğ̈̈slerine derin kesikler atarak, yüzlerini, kollarını ve kafalarını kanla sıvıyorlardı. Samandan yapılan kuklayı şehir dışına çıkardıktan sonra onu yakıyorlar ve kendilerini zincirle dövüyorlardı (Kotov, 1959, s. 33).

\section{Kurban Merasimi}

Kurban bayramında imkanı olan insanlar koyun veya kuzu keserken, imkanı olmayanların tavuk kestiği görülmekteydi (Careri, 1969, s. 95). Safevi Devleti'nde evlerde kesilen kurbanların yanı sıra başkent İsfahan'da büyük bir merasim gerçekleşirdi. Bayramdan üç gün önce erkek bir deveyi çeşitli çiçeklerle, yeşil yapraklarla ve çam dallarıyla süslerlerdi (Pietro Della Valle, 1348, s. 108). Devenin üzerine üç tane çocuk bindirilirdi. Ellerinde ok, yay, satır ve mızrak bulunan bir kaç kişi de devenin önünde yürürdü. Bu şekilde deveyi bayram gününe kadar tüm mahallelerde ve sokaklarda dolaştırarak sadaka toplarlardı (Careri, 1969, s. 95). Devenin önünde ayrıca çeşitli müzik aletleri çalan insanlar ve dini sözler okuyan bir molla vard. Deveyi gören insanlar ise devenin tüyünden bir tutam alabilmek için uğraşırdı. Bunun için bazen izdiham oluşuyordu. İzdihamı ellerinde sopalar bulunan kişiler engellemeye çalışıyordu. Tüy yolabilenler bunu uğur için saklardı (Kotov, 1959, s. 29; Pietro Della Valle, 1348, s. 109).

Bayram sabahı güneş doğmadan önce kalkılırdı. Bayram namazını kıldıktan sonra tüm emirler, halk ve hatta şah salavatlarla kurban töreninin gerçekleşeceği yere giderdi (Pietro Della Valle, 1348, s. 109). Kurban edilecek deve şehir dışına doğru götürülürdü. Onun önünde mızrak ve balta taşıyan insanlar bulunurdu. İsfahan ve Tebriz grubu olarak bilinen iki büyük topluluk zincirlerle ve çıkardıkları yüksek seslerle devenin ardından yürürdü. Deveyi götürdükleri alan önceden temizlenir ve hazırlanırdı. Deve alana getirildikten sonra Şah, hanlar, sultanlar, şahın maiyeti, hizmetçileri, tüccarlar, elçiler eşleri ve çocuklarıyla alana gelirdi. Devenin ayakları bağlanır ve hareket etmesin diye 30 kasap onun ayağı ile başına otururdu (Kotov, 1959, s. 29). Burada izleyicilerden oluşan büyük bir halka meydana gelirdi. Seçkinler at üzerinde en ön safta dururdu. Çeşitli mahallelerden gelen gruplar ise

\footnotetext{
${ }^{6}$ Haydari ve Nemati olarak bilinen ve birbirine düşman olan iki mahalle arasında sık sık çatışma yaşanmaktaydı. Detaylı bilgi için bkz. (Perry, 1979)
} 
onların arkasında, merasimi görmek ve devenin etinden biraz alarak mahallelerine götürebilmek için beklerdi (Pietro Della Valle, 1348, s. 109).

Kurban kesiminden önce Şah atın üzerinde Fatiha okurdu. Fatiha'yı bitirdikten sonra İsfahan Darugası'na ${ }^{7}$ el sallar ve merasimin başlama işaretini verirdi (Kotov, 1959, s. 30). Bazen de attan inerek mızrağı üç kere öper ve ardından darugaya verirdi (Keampfer, 2018, s. 172). Bunun üzerine daruga mızrağı taşıyan adamdan mızrağı alarak devenin kalbine saplardı. Mızrağı öylece bırakır ve geri dönerdi. Bunun üzerine Şah, elçiler, tüccarlar ve diğer emirler oradan uzaklaşırdı (Kotov, 1959, s. 30). Ardından kasaplar devenin kafasını vücudundan ayırırdı. Derisini yüzmeden, her biri şehrin 12 mahallesi için olmak üzere 12 parçaya bölerlerdi. Kurbanın bağırsakları, yüreği ve başı Şah'ın sarayına gönderilmek üzere hazırlanırdı (Keampfer, 2018, s. 173). Ardından et mahallelere dağıtılmak üzere alınıyordu. Etin bir kısmı da İsfahan civarındaki köylere veriliyordu. Kalan et ise halk tarafindan çok hızlı bir şekilde yağma ediliyordu. Bu etin bir parçasını aynı gün yiyorlar, diğer kısmını ise tuzluyorlar ve tüm yıl boyunca hastalı̆̆ defetmek ve şifa bulmak için saklıyorlardı (Pietro Della Valle, 1348, s. 111). Herhangi bir et elde edemeyen kişiler de en azından kurban kanını alnına sürerek oradan ayrılmaktaydı (Keampfer, 2018, s. 173). Et kapma yarışında bazı ölümler de gerçekleşebiliyordu (Don Garcia, 1984, s. 311).

Kotov, Şah'ın saraya dönmesiyle birlikte kurbanın başı ile yapılan bir mücadeleden bahsetmektedir. Şah, devenin başı geldiği zaman, yanında beyler, elçiler ve tüccarlarla birlikte balkona çıkmıştı. Mücadele başlamadan önce devenin başı balkonun önüne getirilerek şaha gösterildi (Kotov, 1959, s. 30). Şah'ın ettiği dua ile birlikte devenin başı meydana götürüldü. Burada Tebrizliler ve İsfahanlılar arasında devenin başı için, ölümüne büyük bir savaş başladı. Hangi taraf kazanırsa devenin başını alır, Şah'a götürür, Şah da bu grubu ödüllendirirdi. O gruplarla birlikte olan herkes bu mücadeleye girmek zorundaydı. Girmeyen olursa Daruga tarafindan azarlanıyordu (Kotov, 1959, s. $31)$.

Kurban bayramı kesilen etlerin yenmesi ve çeşitli eğlencelerle devam ederdi. Kendi evlerinde eğlenme imkanı bulamayanlar meydanlarda ve kahvehanelerde toplanırdı. Buralarda tütün içer ve sokak sanatçılarının gösterilerini izlerlerdi. Üç gün süren bu bayramda tatil yaparlar, gece geç saatlere kadar eğlenirlerdi (Keampfer, 2018, s. 173; Kotov, 1959, s. 31). Ayrıca bayram günleri "Halifet'ül hulefa" şahın huzuruna elinde şeker dolu bir kap ile çıkarak şahın bayramını kutlar ve dua ederdi. Şah, üzerlerine dua edilmiş olan şekerlerden küçük bir parça aldıktan sonra ileri gelen emirlere verirdi. Emirler şekerlere hürmet göstermek için onu başlarının üzerine koyardı (Sanson, 1346, s. 56).

\section{Nevruz Merasimi}

Safevilerde kutlanan ve dini olmayan tek bayram nevruzdu. Nevruz İslamiyet öncesi Türklerde "Yeni gün", "Bahar bayramı" ve "Ergenekon bayramı" gibi isimlerle kutlanıyordu. Daha sonraki yüzyıllarda Farsça bir kelime olan "Nevruz" kelimesini ile bu bayramı kutlamaya devam etmişlerdir (Mustayev, 2013, s. 60).

21 Mart'ta, tabiatın yeniden canlanışını sembolize eden bu bayram ile baharın gelişi kutlanırdı. $\mathrm{Bu}$ günde herkes yeni elbiselerini giyer, arkadaşlarının evini ziyaret eder, yemekler yer ve gezilere giderdi (Keampfer, 2018, s. 133). Yeni y1lı yeni elbiseler ile karşılamanın tüm yıl boyunca uğur getireceğini düşündükleri için, parası olmayanlar bile borç alarak yeni elbiseler alıp giymeye özen göstermekteydi (Careri, 1969, s. 147).

Nevruzun gelişi başkentte ve büyük şehirlerde 3 adet top atışı ile ilan edilirdi. Yeni ve güzel elbiseler giyen Müneccimler, yeni yıldan bir iki saat önce ellerinde usturlaplar ile saltanat sarayının çatısına çıkardı. Orada gözlem yapar ve yeni yılın gelişinden emin olduktan sonra bunu top atışlarıyla

\footnotetext{
${ }^{7}$ Safevi teşkilatı içerisinde önemli bir yere sahiptir. Bu ünvana sahip olan kişiler genellikle hassa topraklarına gönderilir ve bulunduğu yerlerin vergisini toplayarak düzeni sağlardı.
} 
ahaliye bildirirlerdi. Ardından davullar ve diğer müzik aletleri çalınır ve genci yaşlısı, kadını erkeği herkes sevinç ve neşeyle nevruzun gelişini kutlardı (Chardin, 1993, C.I, s. 451). O gece kimse uyumazdı. Tüm sokak ve caddelerde müzik aletleri çalınırdı. Akşam olmasıyla birlikte dükkanlar temizlenir, badana yapılır ve çeşitli çiçeklerle süslenirdi. Dükkanlarda ve evlerde herkes sabaha doğru gücünün yettiği kadar mum yakardı. Bu mumlar yaklaşık 3 saat yandıktan sonra söndürülürdü. Ardından dükkanlar kapatılır ve herkes evlerine dağılırdı. Bu günde ticaret yapılmazdı. İnsanlar bu günü sadece eğlenerek geçirir ve meydanlarda yapılan çeşitli oyun ile eğlencelere katılırdı. Böylece üç gün boyunca eğlenceler sürerdi (Kotov, 1959, s. 26). Yumurtanın bir yaşam kaynağı olduğunu düşündükleri için bu günde birçok yumurtayı çeşitli renklerle boyayarak süslerlerdi. Şahlar için her yıl altın suyu ile renklendirilmiş ve üzerinde çeşitli minyatürlerin nakşedildiği 500 adet yumurta yapılmaktaydı (Chardin, 1993, C.I, s. 452). Nevruz günü bereket için, İnsanlar halının üzerine, sahip oldukları şeyleri yayarlar ve tabak içine koydukları paraları kendi üzerlerine dökerlerdi. Az parası olan kişiler bunu defalarca tekrarlardı (Kotov, 1959, s. 26).

Şah'ın sarayında ise nevruz törenleri 8 gün sürmekteydi. İlk gün Şah ziyafet verirdi. İkinci gün alimler, bilginler ve astrologlar, üçüncü gün Zerdüştlerin reisleri, dördüncü gün kadılar, beşinci gün emirler ve ayanlar, altıncı gün kendi akraba ve yakınlarını huzura kabul ederdi. Sonraki iki gün ise Şah'ın çocukları ve kadınlarına ayrılırdı (Chardin, 1993, C.I, s. 450). Huzura çıkan emirler imkanları dahilinde Şah'a altın sikkeler hediye ederdi. Uzak yerde oldukları için gelemeyenler de iyi bir şekilde giydirilmiş olan köle ve cariyeler gönderirdi (Careri, 1969, s. 146; Chardin, 1993, C.I, s. 452). Ahmed Dürri Efendi, Nevruz dolayısıyla Şah Hüseyin'in huzuruna çıkan emirlerin verdikleri hakkında şu notu düşmüştü;

...bil-cümle vüzerâ ve ümerâ â'yân-1 devlet Şâh'ın meclisine cem' olurlar önüne beşyüz bin altun mikdârı altun korlar Şâh anı eliyle karışdırur bir kabza alub ibtidâ i'timad-üd-devle'ye virür sonra cümle hazâr-1 meclise bahs iderler Şâh'ın eli dokunmuşdur deyu halk birbirine teberrük ve ihdâ ider. (Ürkündağ, 2006, 56)

Şah bu hediyelerden bazılarını hazineye devreder, bazılarını ise kendisi, çocukları, kadınları ve bazı emirler arasında bölüştürürdü (Chardin, 1993, C.I, s. 452).

\section{Sonuç}

Özellikle XVII. yüzy1la ait gözlemler üzerinden Safevi Devleti'nde düzenlenen düğün, ölüm, yas ve bayram merasimlerinin nasıl yapıldığı konusu kısmen ortaya çıkarılmıştır. Buna göre Safevilerdeki Şiilik, yapılan merasimlerde önemli bir rol oynamaktaydı. Bunun yanı sıra Türkmenlerin bazı merasimlerde eski geleneklerini sürdürdüklerini gözlemleyebiliyoruz. Özellikle cenaze merasiminde ölen kişinin atı, silahı ve eşyalarının cenaze ile birlikte taşınması bu duruma güzel bir örnek oluşturmaktadır. Şiiliğin en baskın olduğu merasim ise şüphesiz Muharrem ayı merasimiydi. Hz. Hüseyin'in anısına Muharrem ayının 10'una kadar camilerde ve sokaklarda anma merasimleri gerçekleşirdi. Dini merasimlerden bir diğeri ise kurban kesmekti. Başkentte tüm insanların iştirak ettiği bir törende deve kesilir ve halka dağıtılırdı. Nevruz ise Safevilerde kutlanan tek milli bayramdı.Türkmenlerin Orta Asya'dan beri kutladıkları bu bayram, eski pers geleneğinin de etkisiyle çok canlı bir şekilde kutlanmaktaydı. Bu günde ticaret yapılmaz, insanlar 3 gün boyunca sadece eğlenmekle meşgul olurdu. Nevruz, yeni bir başlangıcı ifade ettiği için insanlar Nevruz'un uğur ve bereket getirdiğine inanırdı. Safevi Devleti'nde gerçekleştirilen bu anma ve kutlama merasimlerinin birçoğu günümüz İranında da aynen devam etmektedir. Hatta bazı adet ve geleneklerin Anadolu Türkleri'nde de görüldüğü bilinmektedir. Misal, gelinin düğünden sonra bir hediye alana kadar kayınbabası ile konuşmaması adeti halen daha Anadolu'nun birçok yerinde uygulanmaktadır. 


\section{Resimler}

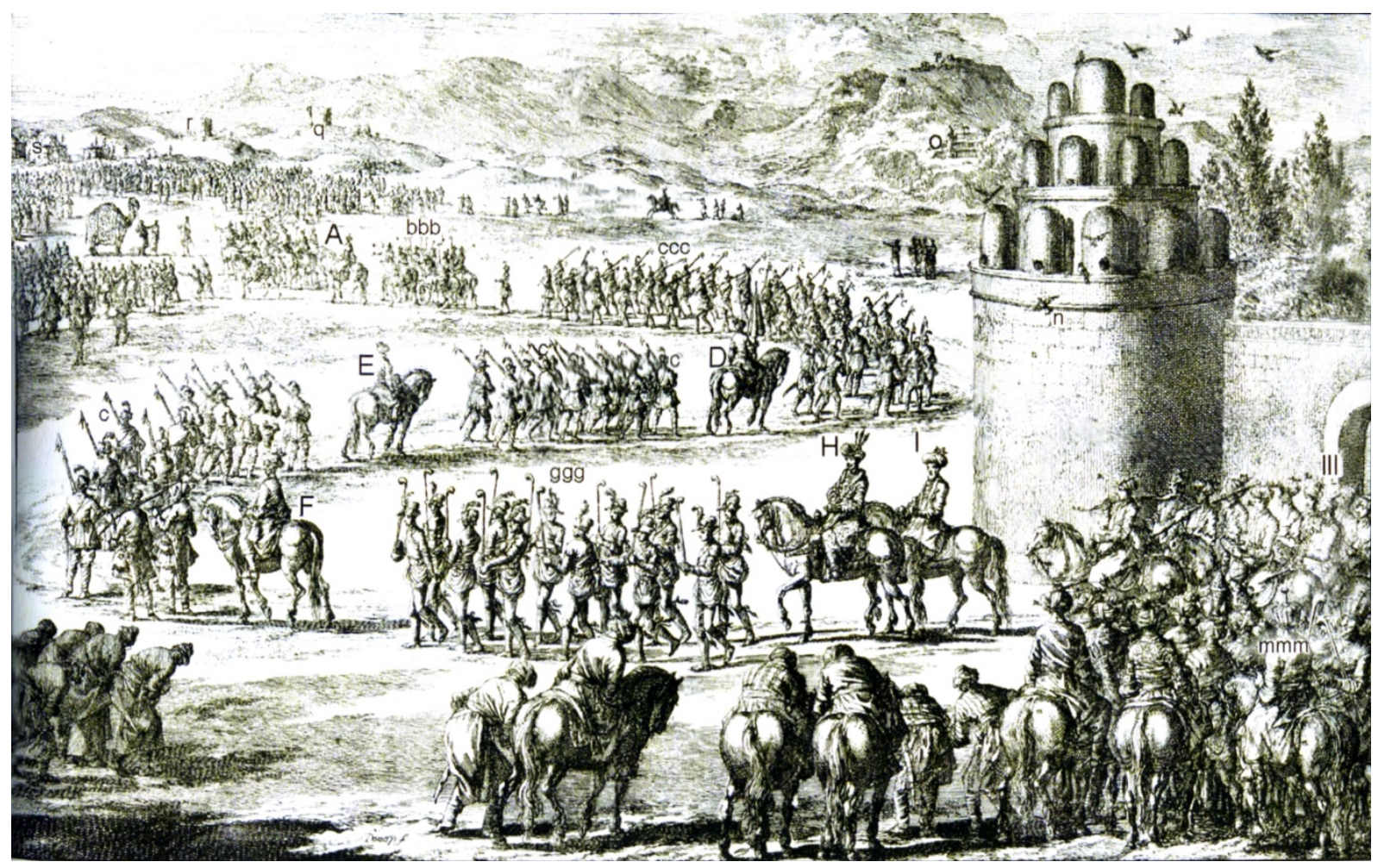

Resim 1: Kurban Merasimi (Keampfer 2018, 171) 


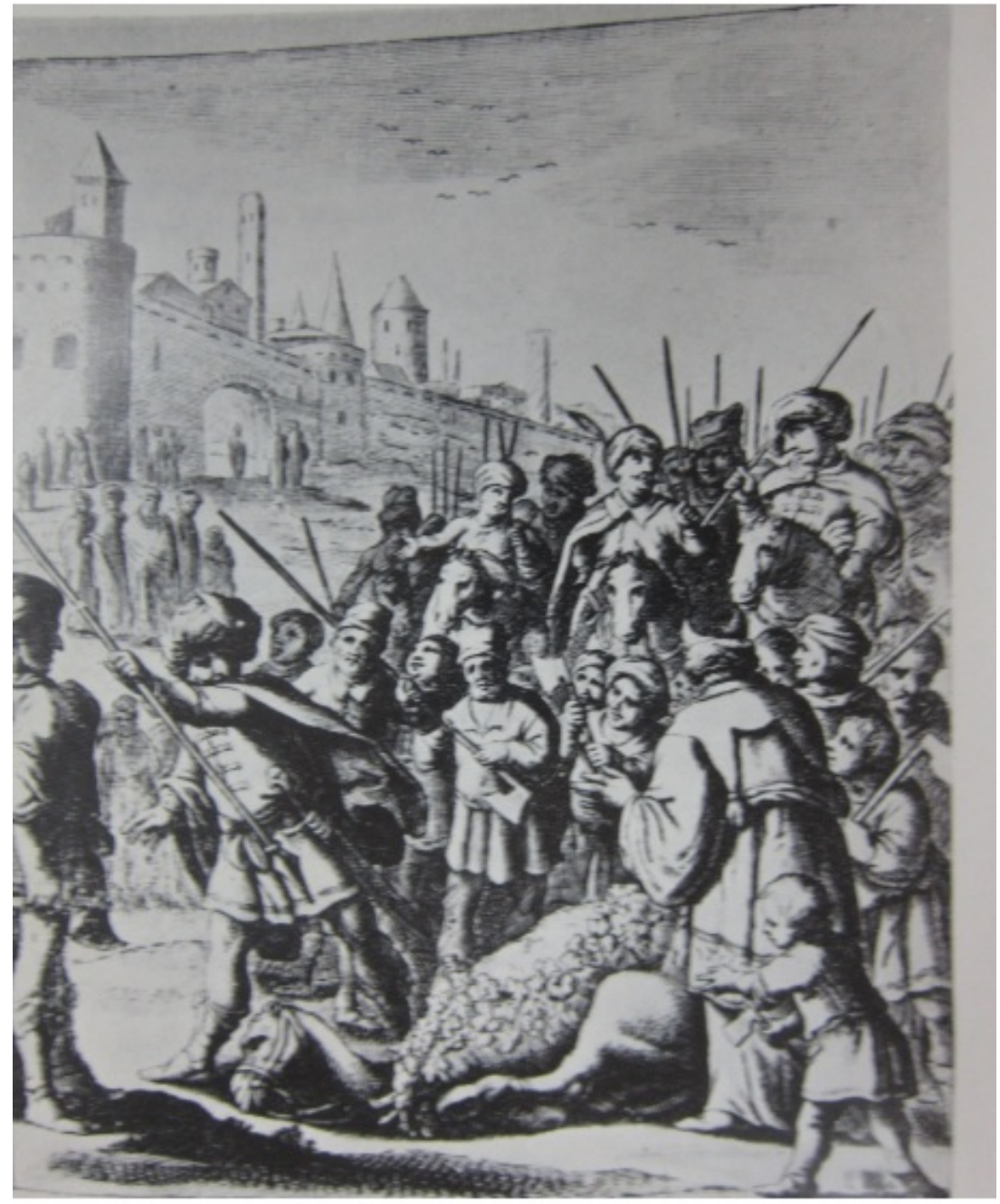

Resim 2: Kurban Merasimi (Pietro Della Valle 1348, 110). 


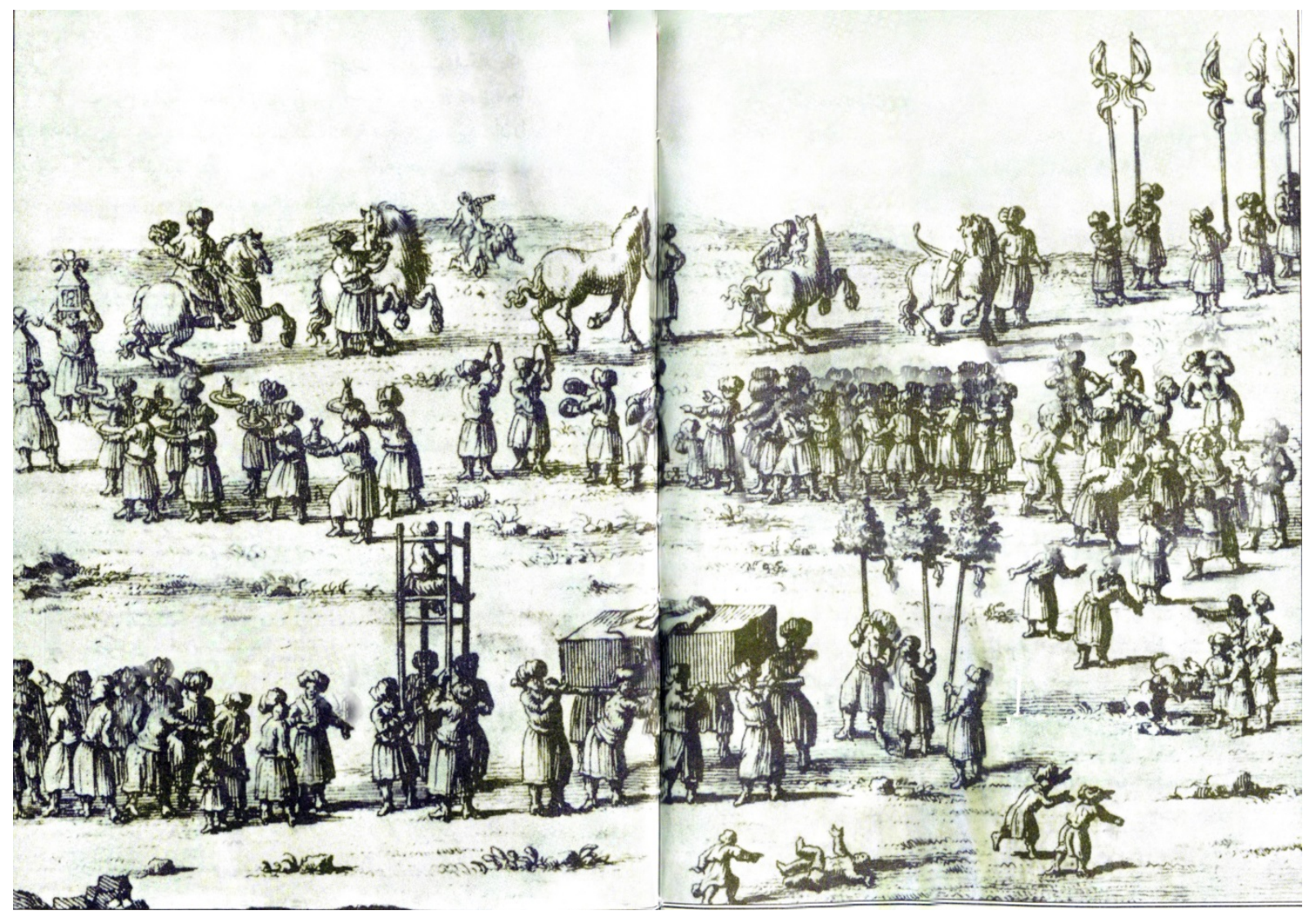

Resim 3: Cenaze Merasimi (Tavernier 1382, 218) 


\section{Kaynakça}

Aydın, M.A. (2003), “Mehir”, DİA, XXVIII, 2003, s. 389-391.

Baş, E. (2004). “Aşûre Günü, “Tarihsel Boyutu ve Osmanlı Dinî Hayatındaki Yeri Üzerine Düşünceler" AÜFD, XLV, S. I, ss. 167-190

Bembo, A. (2007). The Travels And Journal of Ambrosio Bembo, Translated; Clara Bargellini, Edited; Anthony Welch, University of California Press.

Careri, G.(1969), Sefername-i Careri, Terc. Abbas Nahcivani-Abdul Ali Kareng, Tebriz.

Chardin, J. (1993). Sefername-i Şarden, Farsçaya çeviren; İkbal Yağmayi, Tahran, C.I-II.

Don Garcia de Silva Figueroa (1984). Sefername-i Figueroa, Farsçaya çeviren; Gulamrıza Sami', Tahran.

Erdoğan, E. (2015). "Safevi Ordusunda Bir Birlik- Kurçiler", Ankara Üniversitesi Dil ve TarihCoğrafya Fakültesi Dergisi, 55(2): 75-88.

Keampfer, E. (2018). Exotic Attractions in Persia, 1684-1688-Travels and Observations, Translated; Willem Floor-Colette Ouahes, Mage Publishers.

Keser, M. (2019). “Alman Seyyah Engelbert Kaempfer'in Gözünden Şah Süleyman ve Sarayı”, Karamanoğlu Mehmetbey Üniversitesi Edebiyat Fakültesi Dergisi, 2 (1), 7-17.

Kotov, F. A.(1959). "Of a Journey to The Kingdom of Persia”, Russian Travellers to India and Persia (1624-1798), Translated and Edited by: P. M. Kemp, Delhi, ss.1-43

Membre, M. (1993). Mission to The Lord Sophy of Persia (1539-1542), Translated; A. H. Morton, London.

Mustafayev, B. (2013). “Adriyatik’ten Çin Seddine Uzanan Nevruz Geleneği”, Avrasya Uluslararası Araştırmalar Dergisi, Cilt:2, Sayı:3, ss. 60-73.

Olearius, A. (1369). Sefername-i Adam Olearius, Farsçaya çeviren; Muhendes Hüseyin Kordbeççe, C.II.

Oruç Bey Bayat (2014). Illişkiler-Bir Şii/Katolik, Tercüme ve Notlar; Tufan Gündüz, Yeditepe Yayınevi, İstanbul.

Perry, John. (1979). “The Haydari-Ni’mati Conflicts”, Iranian Studies 12, ss. 135-62.

Pietro Della Valle (1348). Sefername-i Pietro Della Valle, Farsçaya çeviren; Şuaeddin Şifa, Tahran.

Sanson (1346). Sefername-i Sanson, Farsçaya çeviren; Taki Tefzali, Tahran.

Santamaría, R.V. (2015). “İspanyol Elçi Garcia De Silva Y Figueroa’nın Gözüyle Safevi Şah Abbas

Döneminde Ziyafet Merasimleri ve Kadınların Durumu”, Yayınlanmamış Yüksek Lisans Tezi, Hacettepe Üniversitesi Sosyal Bilimler Enstitüsü, Ankara.

Tavernier, J. B. (1382). Sefername-i Tavernier, Farsçaya çeviren; Hamid Erbab Şirani, Tahran.

Ürkündağ A. (2006). “Ahmed Dürri Efendi’nin İran Sefaretnamesi”, Yayınlanmamış Yüksek Lisans Tezi, Afyon Kocatepe Üniversitesi Sosyal Bilimler Enstitüsü, Afyon. 